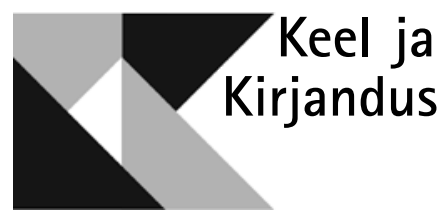

\title{
POEEDIRAHU - ANDRUS KASEMAA KIRJANDUSLIK OMAILM
}

\author{
BRITA MELTS
}

$\mathrm{K}$

äesolevas artiklis vaatlen ning piiritlen kirjandusliku omailmana üht poeetilist-subjektiivset maailma: Andrus Kasemaa ilukirjanduslike tekstidega aegamööda kujundatud ning nähtavaks tehtud Poeedirahu. Termini „omailm” kasutamisel olen lähtunud küll biosemiootilisest Umwelt'ist, aga ilukirjanduslikus kontekstis muundub see vältimatult rohkem või vähem metafoorseks ja antud juhul puutub servapidi ka kultuurigeograafiliste käsitluste valda. Sellisel kujul ühendab omailm endas tõeluse ja väljamõeldise, autobiograafia ja ilukirjanduslikkuse, hõlmates nii tekstides loodud maastikke kui ka nende prototüübiks olevat reaalset, kirjaniku kodupiirkonnaga kattuvat keskkonda; nii autori geograafilist taju, tema siseilma, sihipärast valikut ümbruskonna objektidest ning tema kujutlusi kui ka selle kõige projitseeritust teostesse lüürilise mina või minajutustaja ruumi kuuluvate eksplitsiitsete ja tähenduslike elementide kaudu.

Poeedirahu - väljamõeldud toponüümiga tähistatud ilukirjanduslik koht, millel on tegelik geograafiline läte - on omaette fenomen, mis tingib sellist lähenemist. Artikli eesmärgiks ei ole teoreetiline ammendavus, vaid Poeedirahu kui omailma käsitlus, mis võiks pakkuda hõlbustavat mudelit teiste sarnaste poeetiliste maailmade käsitlemiseks - sest näiteid kirjanike kodukeskkonna või lihtsalt läbitunnetatud ümbruse baasil loodud alternatiivmaailmadest võib leida palju erisuguseid, alates kas või Juhan Liivi Kukulinnast, tehes vahepeatuse Karl Ristikivi Vahemere-äärsetel maastikel või Allotrial ja lõpetades 
uusimate, näiteks Tõnu Õnnepalu Paradiisiga. Neis kumab mänglemine kujuteldava ja reaalse geograafia ähmasel piiril, „isikliku alternatiivmaailma dokumenteerimise võlu" (Jennings 2012: 144), ja selline modifitseeritud versioon pärismaailmast võtab kuju loomingus - kirjanduslike omailmadena.

\section{Poeedirahu - mis ja kus?}

„Poeedirahu on küla, kus pole eriti midagi peale leskede, rebaste ja mahajäetud majade" (Kasemaa 2009b: 115). Tegemist on, nagu juba öeldud, ühe poeetilise maailmaga, tegelikkuse ja kujutluse piiril võnkuva kohaga, mille võimalik paiknemine maastikul jääb kusagile Ida-Eestisse Peipsi kohalt tõusvate pilvede ja üle väljade lõõskavate värskendavate tuulte meelevalda. Eesti kirjandusmaastikule tekkis Poeedirahu 2008. aastal, mil ilmus Kasemaa debüütluulekogu pealkirjaga „Poeedirahu” ja algaski Kasemaa terviklikul loodus- ning maastikutunnetusel põhineva kirjandusliku omailma loomine ühes selle kavakindla täiendamisega subjektiivselt tähenduslike elementide kaudu. Tollal aga ei kujunenud veel Poeedirahust välja mingit üksikasjalist ning sihipäraselt konstrueeritud isiklikku maailma - fiktiivne toponüüm esines pärast esikkogu tiitellehte veel vaid kahes luuletuses, ${ }^{1}$ kinnistades küll koha perifeerset ja ambivalentset, idülli ja kaduvikuõõva vahel võnkuvat iseloomu, ent andmata terviklikku (ruumi/maastiku)tunnetust. Kasemaa teise luulekogu „Lagunemine” (2009) ilmumise järel sai juba kindlamini väita, et kirjani$\mathrm{ku}$ areng või edasiminek on ruumiline ning tema luule on „fundamentaalselt kohaluule" (Tomberg 2009). Nüüdseks on toda omailma järk-järgult väikeste vihjete, märkide ning tähenduslike objektide esiletoomise kaudu kujundatud läbi nelja raamatu: kahele esimesele luulekogule on lisandunud „Kustutamatud ôhtud” (2012) ning proosateos „Leskede kadunud maailm” (2012).

Kasemaa poeetiline kohaloome on toimunud peamiselt neljal viisil: 1) kirjeldatakse loodust (üldnimeliselt, umbisikuliselt) ja antakse geograafilisi märke nii vahetust ümbrusest kui ka eemalejäävatest piirkondadest (Alatskivi, Peipsi järv, Välgi metsad, Kodavere jt); 2) kaardistatakse isiklikku, emotsionaalset või aistilist maastikukogemust ning visandatakse subjektiivne pilt kindlapiirilisest kodukeskkonnast; 3) jagatakse konkreetseid, dokumentaalsusele pretendeerivaid, ent iseäralikke fakte Poeedirahust, selle inimestest ja sündmustest lüürilise mina vahetus olevikus või lähiminevikus; 4) antakse ülevaade ka Poeedirahu ligi sajandipikkusest ajaloost, selle elanikest, majadest, ajas muutunud maastikest (Melts 2010: 46). Kui juurdumuse neljaks tingimuseks peetakse geograafilise maastiku igakülgset tundmist, sotsiaalses suhtevõrgustikus osalemist, emotsionaalsete lähisuhete olemasolu antud paigas ning paikkondlike teadmiste ja intellektuaalse tasandi jagamist (Middleton 1981, viidatud: Tüür 2002: 123-124), siis nende tingimuste kavakindla

\footnotetext{
${ }^{1}$ Poeedirahu kui kohanime esimene mainimine on igas mõttes tähenduslik, sest öeldakse ära, et Poeedirahu on küla ja et see on maailma ilusaim küla (Kasemaa 2008: 9). Teisel mainimisel tundub fiktiivse kohanime esinemine algul juhuslik või koguni pillatud, sest luuletuses ei ole kesksel kohal mitte koht ega küla, vaid raibe, mille ümber noolivad rongad ja varesed (Kasemaa 2008: 47) - ent oma mõttearendusest ette tõtates, siin leidub tegelikult eelhäälestus autori teisele luulekogule ja Poeedirahu edasise kujundamise ühele märkimisväärsele aspektile, memento mori'le.
} 
täitmisega on Kasemaa kahtlemata oma lüürilise mina/minajutustaja juurutanud kirjaniku poeetilisse maailma - omailma.

Nime poolest väljamõeldis, esindabki Poeedirahu ennekõike fiktsiooniruumi. Ent vaevalt lugeja, kes kodumaise geograafiaga pisutki kursis, saaks kuidagi mööda tõsiasjast, et väga suures osas tugineb Poeedirahu tegelikele maastikele, konkreetsetele geograafilistele märkidele, kirjanik Andrus Kasemaa elupiirkonna ehk Alatskivi kandi äratuntavatele detailidele ning tema autobiograafilistele kogemustele (viimases veendumisele aitab kaasa kirjaniku pärisnime kasutamine loomingus). Selle kõigega paigutub Poeedirahu justkui iseenesest Eestimaa kaardile - muidugi mööndustega, ja üldse mitte alati ühtmoodi! Niisiis, hoidugem eksitamistest. Sest: „Jäädes näiteks Arbuusisuhkrust, Kettamaailmast või Gulliveri külastatud maadest triviaalmõttes palju realistlikumaks, peegeldab Poeedirahu ometi tugevasti autori tahtmatuid ja tahtelisi utoopiaid. Maise ja kujutlusliku geograafia kattuvuse määr jääb parasjagu ähmaseks (kord on Poeedirahu üksainus küla, kord jälle ületab piire valdade ja maakondadegi vahel, vt. „Lagunemine” lk. 115 jj.), olemuslikud jooned aga tõusevad reljeefselt esile, seostudes deklareeritavalt autori eelistustega" (Rummo 2010: 590). Enamgi veel, näiteks üksikjuhulise koha/ hoone kirjeldus võib Kasemaal minna sujuvalt üle avaraks maastikuks, nagu luuletuses oma kodumajast: „Kehv maja / kaevu ei ole / kõrvalhoone, ilus ärklituba / laut, viltune saun / tuul puhub seintest läbi / heinaküün, tuules laperdav uks, / mis on alati lahti / pikk hein on kaugel / Ukse all lainetab rohi - / minu armastus / Vaene maa on see / kauge kolkaküla - / minu ilus Eestimaa" (Kasemaa 2008: 12). Poeedirahus justkui ei olekski hoonetel ja maastikel teineteisega sulandumatuid piire, Poeedirahu on korraga nii füüsiline kui ka mentaalne ruum: „...see ilusat nime kandev fenomen ei piirdu ainult reaalsest mahedamaks timmitud geograafilise locus'ega, vaid kandub autoriga kaasa kuhu tahes nii ruumis kui ajas" (Rummo 2010: 590). Väljaspool Andrus Kasemaa loomingut Poeedirahu sellisel kujul ei leia. Võib ju küll tuvastada selle prototüüpse keskkonna, ent tegemist on ennekõike omailmaga, mille tervik kehtestatakse ilukirjanduslike teostega - lugejaile nähtav Poeedirahu on see, mida ja kuidas kirjanik parasjagu tahab oma loomingus esitleda.

Need esitlemised erinevad teoseti. Kasemaa debüütkogus on Poeedirahu visandamine jäänud ennekõike üldnimeliselt looduskeskseks (hoides kiivalt luuletaja isikliku ruumi anonüümsust), kusjuures luuletaja suhe loodusesse on idüllimeeleolu (või poeedi rahu) kinnistavalt lugupidav, koguni ilustav ja helgetooniliselt ülistav, laskumata veel „ümbritseva looduse morni pihustumisse mullakarva algosadeks” (Tomberg 2009), mida kohtab „Lagunemises”. Samuti on „Poeedirahus” jäädud maastike võimaliku paiknemise suhtes oluliselt ebamäärasemaks kui edaspidi: nimeliselt mainitakse esikkogus küll Peipsit, Välgi metsi ja Kodaveret, kuid nende suhtes ei anta konkretiseerivaid suunamääratlusi. „Lagunemine” hakkab küll endistviisi vihjamisi, aga siiski avama ruumilisi koordinaate ning järk-järgult kehtestama Poeedirahu kohalikke ja ometi perifeerseid tunnuseid. Näiteks saab teada, et lähedal on Kallaste ja „Poeedirahu asub 13 miili eemal Kukulinnast”" (Kasemaa 2009b: 115).

${ }^{2}$ Ilmselgelt ei ole tegemist sarnast nime kandva Kukulinna küla ja mõisaga Saadjärve kaldal, vaid kirjandusliku Kukulinnaga, Juhan Liivi „Varjus” kirjeldatud ja väljamõeldud toponüümiga tähistatud kohaga, mille eeskujuks oli Liivi koduküla Rupsi naabruses paiknev troostitu vaesteküla Kitselinn (vt Liiv 1921: 14), kõrgem ala keset sood (Kasemaa 
Ühtlasi kuulutatakse, et varem lihtsalt külaks nimetatud Poeedirahu ühendab endas koguni kolme küla ja on pikliku kujuga nagu loorberileht, ulatudes „otsapidi teise / valda ja teise maakonda" (Kasemaa 2009b: 116) - olles seega luuletajale meelepäraste ja tähenduslike paikade liitmise tulem: „Poeedirahul puudub kindel piir. / Samas jälle ei ületa Poeedirahu läbimõõdult 2 miili. // On kohad mis on siin mu lemmikud ja sealt ka läheb piir. // Ja on kohad mis mulle ei meeldi või / on vaenulikud või seotud halbade mälestustega / või elavad seal võõrad inimesed. // Minu kodu on Poeedirahu süda. / Mina olengi Poeedirahu" (Kasemaa 2009b: 116). Poeedirahu geograafilist iseloomu tingib sügav ja vaikne sisemaa ning lähedal asuv kaunis Peipsi järv. Põhja- ja loodeservast piirneb Poeedirahu metsadega, kus elavad rebased, lõunaservast põldude ja väljadega; selle idaservas asub aga teine küla ja lääneservas elab enim vaeseid inimesi (Kasemaa 2009b: 117). Küla taga on ürgorg, ,all orus on jõgi mis voolab / ja mõis ja kõrged kuused ja munakivitee [---] ja Välgi metsade tohutu ala, / mis algab küla tagant ja lõpeb kuskil / kaugel Palamuse lähedal” (Kasemaa 2009b: 127).

Üksikasjadest ja kirjeldustest hoolimata jääb Poeedirahu „Lagunemisega” veel suhteliselt anonüümseks kohaks, pelgalt oletatava geograafilise ala metafooriks, veel ei saa ka hoolikal lugemisel teada, et Poeedirahu maastikuline prototüüp asub Väljaküla ümbruses Alatskivi ja Pala valla piiril - neid lisandusi ja olulisi täpsustusi toob Kasemaa proosadebüüt „Leskede kadunud maailm" ja sellele lisandunud jutuke ehalkäimisest (vt Kasemaa 2013), milles kirjeldused ja detailid muutuvad veelgi konkreetsemaks, ka suunamääratlustes ja kohanimedes: „Põlluvaheteest kaugel põhja pool algasid Kodavere metsad, need aga polnud midagi läänes asuvate tohutute Välgi laante kõrval" (Kasemaa 2012b: 32). Nii lähemal kui ka eemal paiknevate asulate ja talude mainimine hõlbustab Poeedirahu selget piiritlemist: nimetatakse Pala küla ja Väljaküla naaberküla Kokorat (Kasemaa 2013: 84), viimases asuvat Takulaane talu ja Väljakülas asuvat Ahervarre talu või juba kaugemaid punkte Assikveres ja Punikveres, ning ka hoopis Poeedirahust paarkümmend kilomeetrit lääne poole Pedassaare külasse jäävat kauget Kaiu järve - need on kõik reaalselt olemasolevad kohad. Ühtlasi saab teada, et surnuid maetakse põhiliselt Kodavere kabeliaeda ning et Tartusse on 40 mili (Kasemaa 2012b: 89, 93). Viimasest saab korraga aimu, mil määral on tegemist luuletatud kohaga, mille tekstides antud parameetrid saavad kehtida üksnes kirjaniku peas: Poeedirahu eeskujuks olev Väljaküla koos ümberkaudsete maastikega jääb Tartust veidi enam kui 40 kilomeetri, mitte miili kaugusele, niisiis miilimõõdustikus võib näha tegelikust geograafiast võõritamise otstarvet. Kusjuures sellise toponüümse avameelsuse ja rohkuse funktsioon ei seisne „Lagunemises” deklareeritud ja siiski pelgalt vihjeteks jäänud Poeedirahu piiride ja paiknemise

pruugis „Soku soo liivik”). Liivi omamütoloogiaga suhestudes kirjeldab Kasemaa omakorda Kukulinna paigana, kuhu „saadeti elama lesed, vaesed, vigased, jalutud, poolpimedad ja muidu töövõimetud inimesed” (nagu võis lugeda Kasemaa blogist nüüdseks kustutatud sissekandest 30. aprillil 2009). Paikkondlik side Juhan Liiviga on oluline nii või teisiti, sest Liivist täpselt 120 aastat noorem Kasemaa liigub paratamatult samadel maastikel. Vahetult pärast „Lagunemise” ilmumist ongi Kasemaa oma blogis andruskasemaa.blogspot.com avaldanud, et Poeedirahu, Alatskivi valla üks kõrgemaid punkte, asub Juhan Liivi sünnikodust 14 miili kaugusel (ja Anna Haava sünnikodust üheksa miili kaugusel, jäädes seega nende kahe vahele; kustutatud on seegi sissekanne 6. maist 2009. Viidatud sissekannete tekstikoopiad leiduvad käesoleva artikli autori isiklikus arhiivis). 
hägustamises või paisutamises, see hoopis kindlustab omailma suletust ning silmapiiri (kohad, mis on eemal, on selgelt Poeedirahust „väljas”). Ja ikkagi on kindlustatud ka subjekti, Kasemaa poeetilise figuuri sulgumine, sest ükski lokaalne täpsustus eraldiseisvana ei loo võimalust koha üheseks määratlemiseks ja avalikustamiseks, vaid poetub teinekord teksti üsna juhuslikult (nende ülesnoppimiseks on vaja omamoodi kaardikirge), ja nii toestab ennekõike omailma subjektiivse kujundamise ja seesmise eripära rõhutust.

\section{Omailm}

Hoidun laskumast teoreetilise bioloogia spetsiifikasse, kuid olgu siinkohal ühtteist siiski pikemalt öeldud omailma põhilistest aspektidest, just kirjandusteaduse jaoks olulistest indiviidiomastest ja isendikesksetest eritunnustest. Omailma (sks Umwelt) biosemiootilise terminina lansseerinud Jakob von Uexkülli järgi ei ela me ühtses teiste poolt ette struktureeritud maailmas, vaid isiklikus omailmas, mille me ise endale oma meelte, tahete ja püüdlustega sihiteadlikult ehitame (Undusk 2011b: 19), seades aluseks meid ümbritseva keskkonna selle kõikide komponentidega: „Me ei võta mitte kogu füüsilist maailmaruumi endasse vastu, vaid valime sellest välja asjad, mis meie jaoks on olulised meile antud piiratud ajas. Kuna igaüks meist on surelik, on aeg subjektiveeriv asjaolu, mis sunnib meid suure maailma elementidest oma väiksemaid „elatavaid” omailmu kokku panema" (Undusk 2011a: 125).

Nii või teisiti on igaühe jaoks teda ümbritsev füüsiline ruum alati piiratud, sest piiratud on selle meeltega tajumise ulatus või intensiivsus. Seda piiratud ruumi võime piltlikult kujutleda seebimullina: „Igaüks meist kannab seda seebimulli nagu kõva kesta oma elupäevadel endaga kaasas. See on meiega seotud samamoodi kui meie temaga. Oma seebimulli sees tõuseb ja loojub igaühele meist tema enda päike. Need päikesed on väga erinevad. [---] Omailma all mõistame tervet seebimulli koos kogu tema sisuga" (Uexküll 2012: 200). Niisiis on iga omailm üks suletud üksus, ühe isendi isiklik maailm või „eluruum", mis on täidetud subjektiivselt tähenduslike objektide ja kohtadega, kusjuures kindlad tähendused omistab erinevatele objektidele iga subjekt ise. Vastavalt sellele, milline on objektide tähendus isendi jaoks, „hõlmab elulava kas laiema või ahtama ruumi, mille kohtade hulk ja suurus sõltuvad täielikult vastava subjekti meeleelundite eristusvõimest” (Uexküll 2012: 321). Ühel ja samal objektil on erinevates omailmades erinev (subjektiivne) tähendus, ja mitte ainult: omailmades on objektid sedavõrd ebakonstantsed, et igas omailmas muudavad need koos oma tähendusega ka kuju (Uexküll 2012: 368), olenevalt sellest, milline on iga isendi meeleline eristusvõime ning kuidas on objekti kogetud. Omailma kujunemisel ongi objektilise maailma kõrval võrdselt oluline kogemuste võrgustik (Deely 2009: 23), sest kogemused rikastavad omailma: iga uus kogemus sunnib midagi ümber hindama, annab objektidele uusi tähendusi ka ühe omailma sees ning suunab isendi häälestatust selle suhtes, kuidas ta võib objektile mõjuda ja seda tunnetada.

Iga omailma aluseks on vältimatult tegelik materiaalne keskkond, geograafiline maastik ja sellest väljavalitud punktid (kohad, objektid), loodus koos kõigi oma elementide ja isenditega. Kuid omailm ei ole samane ega ulatuselt kattuv vahetult külgneva füüsilise reaalsusega - subjektiivsel tajul põ- 
hinevana ja bioloogilistest vajadustest lähtuvana on omailm alati tegelikkuse isiklik tõlgendus, reaalse keskkonna derivaat, tahtlik ja valikuline teisend. Ja mitte välismaailm ei suuna ega mõjuta oma eluruumi sulgunud subjekti, vaid subjekt tajub välismaailma sihipäraselt ning mõjub sellele - omailm on „läbi ja lõhki tajuline" (Deely 2009: 92). Nii et ühe omailma eripära sõltub otseselt elusolendi meeltest, tema nägemisvõimest, lõhnatajust, hääletoonide tabamise võimest, puudutustundlikkusest - igaüks reageerib sellele ja märkab väliskeskkonnast seda, mis tema huvi köidab, millel on tema jaoks määrav tähendus ja mis on vajalik. Kõik subjektiivsesse maailma või ühe isendi seebimulli lülituvad objektid on sihipäraselt valitud - ja omailma (objektiline) rikkus sõltub otseselt meeleelundite tajuvõimest. Sest meel, mis saab oma impulsid eeskätt sellega vastavuses olevatest tunnetest või elusolendi siseilmast, kirjutab tähelepanule ette erinevaid suuniseid. Ja nii ongi seletatav järgmine omailmne kirevus: „Leidub inimesi, kes püüavad leida loodusest midagi lüürilist, teisi, kes otsivad sealt midagi heroilist või jutustavat ja saavadki vastavaid muljeid. Nii on mõned omailmad põhijoontes ilusad, teised üllad, kolmandad jällegi melanhoolsed, ja kahjuks on väga paljud inetud" (Uexküll 2012: 202).

Siseilm, mis isendi sihiteadlikkust ja valimisprintsiipi suunab, kujutab endast justkui igaühe sees arendatud tunnetuslikku kaarti, millest omailm pöördumatult sõltub. Sest just siseilm „võimaldab üksikisikul leida oma tee keskkonnas ja siseneda suhtlus-, huvide ja elatusvahendite võrgustikku" (Deely 2009: 84) - siseilm häälestab meeli selliselt, et need võimaldavad füüsilist keskkonda selles liikudes oma huvides ära kasutada, samuti seda keskkonda isendi erivajadustest ja tahetest lähtuvalt ümber kujundada moodustamaks omailma. Näiteks kui lasta end kohalikul elanikul juhtida läbi tundmatu kandi, siis järgib teejuht oma kindlat rada, mida meie ei näe, sest meie meeltele on see võõras: „Tuttav tee sõltub ainult üksiksubjektist ja on seega tüüpiline omailmaprobleem, olles küsimus ruumist ja viidates ühtaegu nii subjekti nägemisruumile kui ka mõjuruumile" (Uexküll 2012: 126). Igaühe kognitiivse või koguni mentaalse kaardi aluseks on üksnes subjektiivsed märgid, kohad ja objektiliste tähenduste võrgustik - keskkonnas ei ole iseenesest mingit asjade olemasolevat kohamosaiiki, vaid see on omistatud subjekti poolt ta omailma asjadele (Uexküll 2012: 96).

Kuna tegemist on puhtalt subjektiivse kuvandiga füüsilisest keskkonnast, teatud mõttes isegi kujutluste reaalsusega, siis ei saa omailma puhul kõnelda objektiivsest tõelusest - nagu juba öeldud, objektiivselt eksisteerivad asjad ei ilmne eales omailmades samasugustena, seetõttu „iga subjekt elab maailmas, mis evib vaid subjektiivseid tõelusi ja omailmad ise kujutavad endast vaid subjektiivseid tõelusi" (Uexküll 2012: 150). Sellise subjektiivse maailma või isegi mudelmaailma puhul, mis iga elusolendi puhul on juhitud erinevatest vajadustest, erinevalt moodustatud ja alal hoitud, kasutades selleks erinevaid tajuorganeid ja kanaleid, ei saa eeldada, et ühe poolt välja antud signaalid on tähenduslikud kellelegi teisele (Tüür 2011: 164-165), et ühe subjekti omailm on äratuntav ja sellisena nähtav mõnele teisele. Samas ei ole see ka üleni välistatud. Omailmaõpetuse järgi polegi võimalik võõra subjekti mõtetele, kellegi teise „minale” või siseilmale vahetult ligi pääseda, kuid seda saab teha kaudselt, uurides ja eristades tema tähenduse kandjaid (Uexküll 2012: 178): „Jälgides, millistele märkidele isend reageerib ja millist tähendust neile omistab, saab vaatleja kokku panna teise liigi või isendi „maailmapildi” ehk 
teisisõnu omailma" (vt joonealune märkus Uexküll 2012: 9). Siin peitub ka üks Poeedirahu avamise võti - määratlemisega, millised objektid on antud juhul tähenduslikud ja millised mitte, on avanenud üks võimalik ligipääs võõra subjekti, Poeedirahu autori omailmale. Sest kui juba üht omailma kujutada - näiteks tekstuaalselt, nagu teeb Kasemaa -, siis selle käigus iseloomulike kogemuste jagamine, elementide kirjeldamine ning subjektiivse keskkonna tutvustamine sillutab paratamatult tee väljaspool seda omailma seisvale vaatlejale selle omailma kas või põgusakski tundmaõppimiseks. Ja enamgi, kuna inimlikku omailma eristab teistest omailmadest ainulaadne erinevus, nimelt tekstuaalsus (Deely 2009: 93), siis selles peitub üks võõraste omailmade mõistmise võimaluse universaalne alus; metafoorika, lausungid, kujundid on erinevatele (tekstuaalselt alal hoitud) omailmadele ligipääsemise tänuväärseiks väravaiks.

Annan endale aru, et käesoleval juhul, nagu üleüldse ilukirjanduslikus kontekstis omailma mõistet kasutades, olen liikunud kujutluslikumale tasandile ning liitnud sellele biosemiootilisest teooriast lahtirebivaid poeetilisi lisatähendusi. Ja mitte päris meelevaldselt: ka Jakob von Uexkülli eesti keeles ilmunud „Omailmade” memuaarses osas nähtub, kuidas inimese omailma osaks on ühtlasi mentaalne sfäär, väljapoole suunatud psühholoogia ja vaimsus koos mõttelise ja lüürilise kvaliteediga - nii et ahvatlust vaadelda ühe lüürilise mina omailma pakub juba Uexküll. Seega siinses kontekstiski ei tähista omailm enam lihtsalt ühe isendi elatavat ruumi kõigi sinna valitud komponentidega, vaid tegemist on reaalse maastiku või keskkonna loomingus kehtestatud vaimse analoogiga või koguni selle baasil kujundatud alternatiivmaailmaga. Selles maailmas võib omailma kujundavat subjekti / autorit ümbritseva tegelikkuse kirjeldamine saada kaetud väljamõeldise ähmastava ja mängulise looriga, mis hoiab ilukirjandusliku maailma täiel määral taandamisest tegelikele geograafilistele maastikele. Ent on selge, et Andrus Kasemaa on oma tekstidega ehitanud endale ühe kirjandusliku omailma nimega Poeedirahu, ja kuigi seda ei saa üksüheselt võtta tekstivälise tegelikkuse või füüsilise ruumina, pole põhjust kahelda selle tõukumises kirjanik Kasemaa isiklikust „eluruumist”. Omailma kujutluse ja reaalsuse määra hindamisel seisnebki küsimus selles, kuidas nimelt on objektiline maailm tahtlikult ja valikuliselt ümber modelleeritud, kusjuures tulemus sisaldab alati ka midagi reaalsest füüsilisest ümbrusest (Deely 2009: 104). Nii ka Poeedirahu puhul.

\section{Poeedirahu objektid ja aistilised maastikud}

Objektistamine võib pealtnäha toimuda juhuslikult ja kogemata. Mis tahes stabiilne ese lihtsalt püüab meie tähelepanu, tahes-tahtmata peatuvad meie silmad huvipunktidel mis tahes vaateväljas - ja paus, meie silmade peatumine, fikseerib objekti. Paus võib olla nii lühiaegne ja huvi liiga põgus, et me ei pruugi olla teadlikudki keskendumisest mingile kindlale objektile; võime uskuda, et oleme lihtsalt silmitsenud üldist vaadet. Sellele vaatamata on need pausid ilmnenud, seega kohad ja objektid fikseeritud. Pole võimalik vaadata vaatepilti üldiselt, meie silmad otsivad paratamatult toetuspunkte, tahtlikku peatust orientiiril või juhuslikku pausi huvi äratanud silmatorkavate tunnusjoontega objektil (Tuan 1981: 161). Igasugust huvi- või tähelepanuäratust on 
suunanud isendi siseilm, inimene võib maailma vallata, kuna tal on tunded ja kavatsused (Tuan 1981: 162). Kõik nähtav - objektide nägemine ja äratundmine - on vastavuses sisemise sunniga, lähtub meie meeltest, tahetest ja püüdlustest. „Tunded on need, mis annavad teatud objektile tema tähenduse antud hetkel ja tõstavad selle objekti tähelepanu valgussõõri, lastes teistel olematusse kaduda” (Uexküll 2012: 253), ning poolhõllandusliku keskkonna kujundamine Kasemaa debüütkogus „Poeedirahu” saigi alguse emotsionaalsete ja meeleliste kogemuste sõnastamise kaudu (Melts 2010: 47), sealsete ja ka „Lagunemise” luuletuste tundeline laetus ümbritsevate maastike suhtes on suurem kui neile järgnenud teostes.

Ja nagu iga omailma puhul, nii teeb ka Poeedirahu autor oma subjektiivse valiku objektidest, nähtustest, maastikuvormidest, mida ta teda ümbritsevast keskkonnast esiteks tunnetab või teadlikult tajub ja teiseks lugejale eksplitseerib. See eksplitseerimine võib olla nii sihilik kui ka tahtmatu, ent kui juba omailma nõnda tekstualiseerida, nagu seda teeb Kasemaa, on omailma nähtavaks tegemine kindlasti sihilik ja saab rääkida koguni Poeedirahu „poeetilisest kompositsioonist” (Kaus 2008). Objektiline maailm ei pea mitte ainult edasi püsima, vaid peab arenema vastavalt selle keskmes oleva subjekti vajadustele ja ihadele, mille suhtes vahetult külgnev füüsiline keskkond on aga üleolevalt ükskõikne - füüsiline ümbrus on igal ajahetkel ja igal juhul see, mis ta on, kuid objektiline maailm on igaühe puhul eriline (Deely 2009: 176), nagu on erilised ka objektide tähenduslikuks ning nähtavaks saamise viisid ja võimalused.

Millised siis on need tähenduslikud objektid, millest konstrueeritakse üht tekstuaalset omailma ja mille abil see omailm, Poeedirahu saab nähtavaks lugejale? Nüüdseks pole kahtlust, et Poeedirahu põhiobjektideks on rebased, mahajäetud majad ja lesed. See asjaolu ei tulnud küll välja Poeedirahu valdavalt maastikukeskseks jäävast avateosest, kuid järgnevas loomingus on Kasemaa seda toonitanud mitmel pool ja mitmel viisil, nii luules, proosas kui ka oma blogis. ${ }^{3}$ Eriti dominantseks on muutunud lesed, keda põgusalt tutvustati juba „Lagunemises”, ent kellest just Kasemaa proosaloomingus on saanud koguni Poeedirahu üks võimsamaid, sümboolsemaid ja määravamaid komponente, mis sellisel kujul on ainulaadne viis oma subjektiivset ruumi objektistada. Kuid kõigest järgemööda.

Luulekogus „Poeedirahu” tulevad esile ja võimenduvad ennekõike puhtlooduslikud elemendid, nagu pilved/taevas, tuuled, metsad, rohi/heinamaa, kuid see kõik jääb, nagu artikli esimeses osas öeldud, valdavalt anonüümseks ja üldnimeliseks - küllap sihilikult, kui lugeda üht mõttekäiku ühe teise omailma kohta: „Üldnimede kasutamine loob teatava umbisikulisuse ja anonüümsuse, mis kannab omaette sõnumit - looduses pole nimesid, pole elulugusid ja seega on looduseks saamine ka vabaks saamine" (Maran 2001: 183). Kirjaniku algne soov oli hoida Poeedirahu anonüümsena, peidus kõige välise eest. Niisiis, kuigi võib juhtuda, et „võililled noogutavad päid / sõbrad ristikhein kastehein / hingavad tasa" (Kasemaa 2008: 14) ning lüüriline mina heidab lesima just kodupärnade alla (Kasemaa 2008: 34, 62), jäävad taimed enamjaolt liigiti eritlemata - Poeedirahu looduslikud objektid kannavad pigem meelelist

\footnotetext{
${ }^{3}$ Juba eespool viidatud blogi andruskasemaa.blogspot.com päises on pealkirjaks asetatud toponüümile „Poeedirahu” lisatud väiksemakirjaline täpsustus „kolkaküla täis leski, mahajäetud maju ja rebaseid".
} 
ja emotsionaalset kui liigispetsiifilist tähendust. Ometi ka sellisel viisil keskendub Kasemaa lüürilise mina kuvandile, aga mitte tema ego erakordsuse kuulutamiseks, vaid esitlemaks tema vabasid ja vabastavaid olemisviise puhtas looduses: vedelemine ja logelemine, lamamine ja lihtsalt, passiivselt vaatlemine, horisontaalsest asendist ümbruskonna imetlevalt takseerimine ning omailma tunnetamine. Juba kaks avaluuletust kuulutavad: „Mulle meeldib vedeleda” (Kasemaa 2008: 4, 5), lõpuluuletus võtab kokku: „Vedelesin pärnade all nagu lõvi” (Kasemaa 2008: 62). See tähendab eelkõige „õues”, avaral maastikul lesimist ning sel viisil Poeedirahuks koonduva keskkonna tajumist ja ülestähendamist. Kuna omailma mõjuruumis ehk meie liigutuste mänguruumis eristame kuut liikumissuunda, mis vastanduvad teineteisele paarikaupa: paremale ja vasakule, üles ja alla, ette ja taha (Uexküll 2012: 90), siis viisist, kuidas Kasemaa lüüriline mina oma keskkonda tajub ning hindab, kujuneb vastavalt ka tema domineerivaks suunaks just vertikaalsus, piirnedes ainuvõimalikult ühest otsast maapinna ja teisest taevaga. Pole siis ime, et lisaks rohu ja heinamaade imetlemisele joovastub lüüriline mina samaväärselt just pilvedest, taevast ja vihmasadudest. [Nt „Armastan vihmaseid päevi ja öid / öö läbi kuulata vihmasadu akna taga / seda ma armastan / seda üksindust täis madalat taevast / mille all on minu kodu ja kruusatee" (Kasemaa 2008: 44).] Sest subjekti omailma on suletud kõik see, mis on parajasti tema jaoks nähtav, andes sellega ka enim tooni omailma struktuurile.

Luuletustesse haaratud loodusobjektid võivad ilmestada autori maailmapilti, väljendada n-ö tema metafüüsilist maailmataju (Maran 2001: 182), ja kõik, mida subjekt näeb, on kooskõlas tema vajadustega (Uexküll 2012: 244), mis võivad tähendada ka puhtalt hingelisi või emotsionaalseid vajadusi. Kui Kasemaa loomingus toob just lesimise horisontaalsuse tähenduslikuks muutumine esile vertikaalsuse, siis vertikaalsuse avastamine omakorda süvendab horisontaalsuse tähenduslikkust, „vedelemine, pikali olek, avab autori ees maailma kihilisuse, selle sügavused ja kõrgused, paneb märkama ja selle kaudu imetlema iseenesest teada-tuntud, nii-öelda käe-jala juures asju" (Kaus 2008), mida võiks illustreerida luuleread: „Sirtsud siristavad / Kõrge rohu seest / paistab taamal / rünkpilvi” (Kasemaa 2008: 61). Või hoopis: „Vedelen heinamaal / ja nuusutan võililli” (Kasemaa 2008: 10). Kõrge rohu sees lamades ja pilvi vaadeldes tajutakse ühtlasi midagi nägemisvälja ulatumatut, mis on juba üldnimelisusest konkreetsem ja kannab kahtlemata isiklikku tähendust: helid, sirtsude siristamine, võilille lõhn. Need aistilised omadused saavad omailma osaks. Lüürilise mina jaoks konkreetsed on ka loomad - koerad, kodused lambad, kes „Poeedirahu” kogus kannavad suurimat tähendusväärtust, toonitades idüllimeeleolu, ja muidugi juba eespool esile tõstetud rebased. Rebased aga ei ole Kasemaa esikkogus veel niivõrd määravateks objektideks kui edaspidi, hoolimata sellest, et raamat on pühendatud „Joonatanile ja rebastele". Alles palju hiljem saavad esialgu ebamäärastest raibete väljakraapijatest „Mu rebased”, kes „nutavad õhtul / väljade peal” (Kasemaa 2012a: 27), need rebased, kellest kujunevad Poeedirahu kesksed tähenduskandjad ja ühed põhiiseloomustajad.

Olgu öeldud, et Kasemaa esikkogus tajutud ja registreeritud objektid ja nende omadused ei ole tegelikult midagi erilist, nii et Poeedirahu algusjärgus ei lase luuletaja meid oma omailmale üldse väga lähedale. Tema „meeleelundite tajupidemeta maailm (tajuilm)" ja „liikumiselundite maailm (mõjuilm)” 
(Uexküll 2012: 252) on suhteliselt ahtakesed. Niisiis ei loo Kasemaa oma esikkoguga mitte objektide poolest rikkalikku, vaid üsna lagedat ja monotoonset, aga seda enam stabiilset ja „turvalist”, pastoraalset rahu pakkuvat maailma: „Mööda teed tõuseb vahel tolmukeeriseid, / taamal sinetavad alati ilusad Välgi metsad / Poeedirahu on vist maailma ilusam küla” (Kasemaa 2008: 9); „Taevas on nii sinine / avar / heinamaade / viljapõldude kohal / kohisevate laante / ja metsade kohal" (Kasemaa 2008: 21). Ja seda enam on tähelepanuväärne, mil määral kasutab Kasemaa oma lüürilise keskkonna kirjeldamisel aistiliste või meeleliste tunnuste esiletoomist. Kui lihtsalt kellelegi tuttava tee või maasti$\mathrm{ku}$ äratundmine sõltub vahetult tema kirjeldamise laadist ja kirjeldamiseks kasutatakse üldjuhul kolme liiki tunnuseid: optilisi, koordinaatsüsteemi suunatähiseid ja suunasamme (Uexküll 2012: 127), siis puhtsubjektiivse, isikliku ruumi kirjeldamisse lülituvad vältimatult aistilised tunnetused: näiteks Poeedirahu kruusateede puhul ei olegi oluline nende suund ja ulatus, vaid nendelt kerkiv tolm, see, millist mõju avaldavad teelt tõusvad tolmukeerised lüürilise mina seisundile, mõtisklustele. Seetõttu lubatagu Poeedirahu juures rääkida „aistilistest maastikest” või „meelte maastikest”, nagu neid on nimetatud kultuurigeograafia vallas: need on maastikud kui paljude tundeelamuste allikad, mille vahetusse tajumisse on lisaks visuaalsele kätketud ka kõik lõhnade, häälte ja puudutustega seotud naudingud (Bunkše 2012: 60-61), samuti teadvusesse kanda kinnitanud mälestused, elamused ja kujutluspildid. Rohi Poeedirahus lainetab, nii muru kui ka mullapinnas on lõhnav ja pehme (Kasemaa 2008: 40), „Vanades telefonitraatides undab tuul / ouuekases mühisevad lehed / küüni uks laperdab tuules / ja heinaküün ise kääksub / nagu vana laev" (Kasemaa 2008: 11); lüüriline mina lesib „sahisevas õhtuses tuules” (Kasemaa 2008: 34) ning „Kõik, mis mul kord kõigest / meelde jääb on see tuul, / jahutav tuul väljade pealt / mille keskel on mu kodu" (Kasemaa 2008: 54) - väliskeskkonnast tulevat otsest ärritust tajub lüüriline mina jahutava tuuleõhuna oma ihul niivõrd intensiivselt, et see kutsub temas esile kodutunde ning mäluruumi ühtesulamise tuuleõhuga.

Ent kui sissejuhatuses peatusin põgusalt Poeedirahu kui koha ambivalentsel iseloomul, mis võrdselt võngub idüllilise meeleolu ning õõvastava lagunemise/kadumise vahel, siis see võnkumine saab peamise hoo just „Lagunemises", kus küll endistviisi peesitatakse ka päikese käes ning vahitakse lambaid, kuid sellest enam hakkavad tähenduslike objektidena esile tulema juba räämas mahajäetud majad, lesed, roiskuvad raiped, mis toovad Poeedirahusse dekadentlikku ja tumedat meeleolu, resignatsiooni - isegi tuules, nii meeldivalt jahutavas, võib nüüd olla midagi ähvardavat, „Tuule tugevnedes tumeneb kõik" (Kasemaa 2009b: 17), ning perifeeria puutumata looduse ilu imetlemise kõrval võib tunda ka olemise igavat, rasket ja sünget poolt. (Sellega ühendub surmatemaatika, millest aga järgmise alapealkirja all.)

Selle kõigega avaldub kirjaniku üha süvenev minevikuhuvi ja ajamõõtme paisutamine vähemalt sajandipikkuseks - põhiliselt annavad selle võimaluse Poeedirahu lesed ning nende kaudu minevikumaastikud, mida samamoodi kirjeldavad ennekõike meelelised tunnused. See tähendab, et Poeedirahu üheks osaks on lõhnad ja hääled ka leskede ammusest maailmast, nagu näitab proosateos „Leskede kadunud maailm”. Viimasega avalikustub, kuidas Poeedirahu üheks aluseks on tegelikult hõllanduslikud maastikud kaugest ajast, mida lüüriline mina või minategelane ise ei ole sellisena kogenud. Korraga on 
Poeedirahu subjekt - kirjanik või temaga suuresti kattuv lüüriline mina/minajutustaja - üle võtnud võõrad mälupildid, oma objektide meelelised maastikud ning subjektiveerinud need (üksikutes kohtades esindab „mina” hoopis leskede häält ja vaatepunkti!), teinud need enda omaks, luues nende põhjal oma kujutluste reaalsuse. Kasemaa proosas esitatud lapsepõlvemälestused seostuvad ja isegi piirnevad just leskedega. Sellega kirjanik justkui õonestab enda kehtestatud omailma vankumatust ja vaikelule toetuvat turvalisust subjekt ähmastatakse, segades tema positsiooni ja vaatepunkti tema objektide häälte ja sõnadega. Enamgi veel, kui subjekt tunnistab luhtumist: „Sõnad ei suutnud mind iial viia tagasi minevikku, kuigi ma uskusin, et lesed on nagu ajamasinad, mis lubavad rännata kaugesse aega" (Kasemaa 2012b: 22), siis tähendab see ka Poeedirahu kui omailma luhtuvat tendentsi. Kui subjekt kujutleb end oma objektide vaatevälja ja hakkab sedasi ise hajuma, on hajunud ka omailma üks tingimus. Ja minajutustaja tunnistabki kadunuks Poeedirahu ühe külje, mineviku meelelised maastikud: „See maa, kus lesed kord elasid ja mida ma nüüd nii näha tahtsin, oli kadunud" (Kasemaa 2012b: 22).

Ent Poeedirahu ei luhtu, selle subjekt tunnetab enese piire kindlamini kui näib. Sest seesama kujutlus - leskede mälupiltide põhjal oma subjektiivse maailma konstrueerimine -, mis võib omailma õõnestada, esindab siin ei rohkem ega vähem kui omailma kujunemise tingimuseks olevat valikulist ja tahtejärgset suhtumist füüsilisse keskkonda, seega subjekti siseilma ja vajaduste kehtestamist. Kusjuures oma objektide, leskede mäluruumi hõlvamine võiks olla üks viis lasta lagunemismeeleolul ja süngusel pöördumatult võidule pääseda, nagu juhtus „Lagunemises”. Ent Kasemaa valib teise võimaluse: ajalugu, kaduvus ja kaotused kaetakse luuleliselt leebe ja romantilise nostalgiaga, millega kirjanik ilustab oma Poeedirahu, üht „vana ja turvalist maailma”. Seda toetavalt esitletakse veel püsivaid, kas või üksikuid ajamõõdet ning nostalgiat märkivaid objektilisi tähiseid, mille tähendus võib olla oodatust palju suurem, näiteks: „Meie aia ääres oli neli suurt lese istutatud hõbepaju. [---] Aga see hõbepaju, kus mul onn oli, on tänini alles ja kaugelt vaadates üks kõrgemaid Poeedirahu puid" (Kasemaa 2012b: 39-40). Luuleski, nimelt Kasemaa kolmandas kogus „Kustutamatud õhtud”, taastatakse „Lagunemises” õonestatud idüllimeeleolu ja „Poeedirahus” ilmsiks tulnud lüürilise mina üks põhitegevus, haljal aasal või heinamaal pikutades ja logeledes pilvede vahtimine: „päev otsa vaadata tõusvaid suuri pilvi / kerkimas horisondi tagant / üles üles / erinevaid kujusid võttes / päev läbi / sinine sinine taevas / valged pilved" (Kasemaa 2012a: 64). Aistilisi elamusi ja emotsionaalseid õhinaid pakkuvad maastikud libisevad siin taas Poeedirahu heledamal poolel: lehtede kahin toob hinge taas rahu, lõhnad on jälle meeldivad, silmapiiril domineerivad puhtad ja kaunid vaated, olemises valitseb poeetiline kergus...

\section{Memento mori}

Kuidas saab surmatemaatika, midagi nii piiravat ja lõplikku, olla seotud omailma esitlemisega, kuidas saab surm olla omailma objekt? Siin tuleb lähtuda sümboolsest tasandist ning surma nimetamist ilukirjanduslikus tekstis võtta peamiselt personifitseerimise ja ühes sellega teadliku objektistamise aktina, sest tähendus, mida subjekt või lüüriline mina surmale omistab, on vaadel- 
davas omailmas niivõrd jõuline, et saab Poeedirahu paratamatuks iseloomustajaks. ${ }^{4}$ Pealegi võib surmas sisalduda mitte lagundav, vaid subjektsusest teadlikolekut kinnistav tendents, kui lugeda Heideggeri-käsitlust: „Surm, mis mind tabab, on rõhutatult minu oma, seda esmalt tähenduses, et inimene sureb ikka oma surma. Suhestudes surma kui oma surmaga, muutub mu arusaam endast ja olemisest tervenisti: saavutan oma päris ise" (Parhomenko 2009: 242). Isendi omakeskse maailmana nõuabki omailm teadlikkust ja lähtumist „oma päris isest”, et sellest sõltuvana valida füüsilisest keskkonnast üksnes vajalikke ja soovitud asju oma isiklikku elukeskkonda lülitamiseks surelikkuse teadvustamine või mäletamine, memento mori silmapiiril hoidmine niisiis toestab subjekti enesekesksust.

Poeedirahu leskede, minevikumaastike, õõvastava kaduvikumeeleolu ning baudelaire'ilike roiskuvate raibetega kaasneb surmatemaatika igal juhul ning luulekogus „Lagunemine” on memento mori sedavõrd möödapääsmatu, et surm omandabki objekti staatuse. Jääb üle vaid tõdeda, et Poeedirahu üheks ehituskiviks ongi muu kõrval ka surm, mis pöörab ümber Kasemaa debüüdis loodud helgematoonilise ja rahuliku mulje ning asendab selle hämara, sünge rahutusega. Surmast tingituna kerkivad jõuliselt esiplaanile sellised Poeedirahu iseloomustajad nagu lagunemine, kõdunemine, mädanemine, raiped, tuhk, üleüldse „ümbritseva looduse morn pihustumine mullakarva algosadeks" (Tomberg 2009) - maastike aistilisus väljendub siin kõiges muus kui „Poeedirahus” täheldatud kaunis taevasinas, õrnades loodushäältes ja meeldivates lõhnades. Surma vältimatuse ja halastamatusega rõhutatakse metsikut, robustset, naturalistlikult argist maailma ja loodust, „kus kevaditi näljased rebased maa seest raipeid välja kaevavad [---] ja üksik vanamutt kärvab oma majas sama vähe poeetiliselt nagu vana haige koer" (Vaarik 2009: 88), niisiis oma teise luulekoguga Kasemaa justkui tühistab selle idüllilise looduse, õndsa omailma, mida ta oma esimeses luulekogus kehtestama asus. Või siiski mitte?

Surma teema algab tegelikult juba esimeses Poeedirahu tutvustavas tekstikogus: lüüriline mina on algusest peale oma surelikkusest teravalt teadlik ning kuulutab üsna kiiresti, et kui ta kord sureb, ei taha ta saada maetud pimedasse surnuaeda, maa alla, kus tal hakkab igav ja külm, vaid hoopis „puu alla pikali lamama, / et ma saaksin pilvi vaadata”, ja samas luuletuses püütakse tegelikult surma jubedust ja rõhuvust lahjendada: „Kui ma kord suren / olge rõõmsad / nagu oleks Kasemaal sünnipäev” (Kasemaa 2008: 7). Subjekti seotust surmaga esitatakse siin veel ilmselge pastoraalse rahuga ja helgelt, hoides avarat maastikku ning taevast igaviku silmapiiriks, laskmata lahti deklareeritavast $\mathrm{nn}$ vedelemisfilosoofiast. ${ }^{5}$ Kogu rahuliku vaikelu kõrval saadab luulekogus „Poeedirahu” surmatemaatika pidevalt idüllilisi looduspilte ning isiklikke joovastusi - ja tõepoolest, siit võib leida ka „Lagunemise” põhiteema:

${ }^{4}$ Memento mori's võib näha lüli, mis ühendab siinkirjutajat enim huvitavaid omailmasid: Poeedirahu lesed, raiped ja kabeliaed; Õnnepalu Paradiisi kaduvikuhõng, kuna kõik on sealt lahkunud ja seal pole kellelgi lapsi; Traadi Harala kalmistult kajavad epitaafid; lõpuks ka Ristikivi Arkaadia, mida võib tinglikult näha „Rooma päevikus” suubumas hulluse ja surma labürindiks...

${ }^{5}$ Sellise avatud maastikule lageda taeva alla maetud saamise soovi juurde tuleb Kasemaa tagasi ka oma kolmandas luulekogus, kuid siin teadvustab lüüriline mina oma „Lagunemises” dominantseks saanud põrmustumist mullaks: „Kui ma kord suren / matke mind leskede aeda / nende õunapuuaias / ma puhata tahan / pilvi vahtida / mullaks jääda” (Kasemaa 2012a: 32). 
„Kõik maast kõrgem / laguneb taas mullaks / Elu on nõiutud surm” (Kasemaa 2008: 38). Aga kuigi algusest peale saab jälgida lüürilise mina kohtumisi surevate loomade ning jäledate korjustega, ei muutu ükski neist objektidest esitletavas keskkonnas dominantseks ega morbiidset olustikku rõhutavaks. „Poeedirahus” kuulub surm lahutamatusse ja vältimatusse, ent harmoonilisse kolmikusse koos armastuse ja eluga (Kasemaa 2008: 44) ning on ennekõike midagi igatsuslik-poetilist, isegi ilusat, kandes rahu, vaikuse, unustuse tähendust (vt Kasemaa 2008: 49); esialgu osavalt igatsuslike ja idealiseerivate nüanssidega markeeritult võib surm, vastandudes armastuse valudele ja piinadele, olla koguni midagi romantilist: „Aga surm - see on rahu / igatsuste õnnis lõpp" (Kasemaa 2008: 57).

Surm „Lagunemises” on varjamatu, pidevalt nähtav, ilge ja õudne, kusjuures mitte üksnes maa seest välja kraabitud haisvate raibete tõttu, vaid järjest hakatakse kirjeldama ka Poeedirahu elanike suremisi. Ja mitte ainult: „Mu elu on aeglane mädanemine jõudeelus / lõputu öö / lõputu mädanemine” (Kasemaa 2009b: 29), teab lüüriline mina oma ajutisust; surmast, lagunemisest ja kõdunemisest saab koguni lüürilise mina fetiš, kui ta avaldab salajase soovi käia koera lagunemist vaatamas (Kasemaa 2009b: 44) või esitab kujutluse oma maetusest ja ussitoiduks pudenemisest (Kasemaa 2009b: 21). Ent sellise eksplitsiitsuse taga kumab vaevalt küll lootusetu õonestamine ja häving, pigem ikka Kasemaa juba tuttav võnkumine ambivalentsuse kütkeis. Kasemaal on ilu alati kõrvuti kaduvusega, armastus lagunemisega, surm õnnelikkusega: „Surm / Sina oled kõige õnnelikum / sest Sina saad nad kõik / keda tahad keda igatsed" (Kasemaa 2009b: 49). Selline on juba kord Poeedirahu, kus tajutav surm võib tekitada poeetilist ja isegi erootilist joovastust, romantilist igatsust või vaikset, leplikku resignatsiooni: ,...on jäänud vaid vaikne küla, surm” (Kasemaa 2012b: 10).

\section{Lõpetuseks}

Andrus Kasemaa on oma loominguga kehtestanud ühe poeetilise maailma, millel on küll äratuntav geograafiline läte, ent mis kujutab endast ennekõike mentaalset konstruktsiooni ja võngub seega tegelikkuse ja kujutluse peibutaval piiril. Poeedirahu on nähtus, mille juures biosemiootilise omailma mudeli kasutamine osutub viljakaks ka kirjandusteaduses, olles ühtlasi üks ahvatlevamaid võimalusi kirjaniku kodukeskkonnast inspireeritud omamütoloogia ja sellekeskse lüürilise mina käsitlemiseks. Nagu igaühe omailm on justkui isiklik seebimull, mille aluseks on isendit ümbritsev keskkond koos kõikide osistega, nii on ka Poeedirahu kirjaniku meelte, tahete ja püüdlustega sihikindlalt ehitatud subjektiivne maailm, mis saab võõrastele nähtavaks üksnes kirjalikus loomingus.

Poeedirahu kui üks kirjanduslik omailm kujuneb ning täieneb teoseti järkjärgult, mille käigus kehtestuvad selle tunnused ja ligikaudsed piirid. Poeedirahu piiride kindlaksmääramisel jääb kirjanik varieeruvaks ning ebaselgeks, deklareerides kõigepealt, et Poeedirahul puudub kindel piir, ning siis jälle kinnitades: „On kohad mis on siin mu lemmikud ja sealt ka läheb piir” (Kasemaa 2009b: 116) - kirjanik hoiab selgeid piire saladuses. Muutlik on ka Poeedirahu ulatus: debüütkogus nimetati seda lihtsalt külaks, üheksainsaks, kuid „Lagu- 
nemises" avaldatakse, et Poeedirahu koosneb tegelikult kolmest külast ja ületab nii valdade kui ka maakondade piire, hõlmates subjektiivselt valitud ning subjektile olulist keskkonda: „Poeedirahu nime panin kolmele külale sest ma elan siin ja ma liigun just nende külade vahel kõige enam” (Kasemaa 2009a). Kasemaa omailma maastikuline prototüüp on aga erinevate avameelsete vihjete ning objektide kaudu tuvastatav, see jääb kirjaniku kodukandiks oleva Alatskivi lähemasse ümbrusse. Seega oma kirjandusliku omailma loomisel kasutab kirjanik varjamatult autobiograafilisi detaile ja kogemusi, aga segab need kujutlustega nii mõõtkava või vahemaade esitlemisel (miilid) kui ka aistiliste tunnuste kirjeldamisel (Poeedirahu kui leskede lapsepõlvemaastikud, nende mälestuste põhjal kujutletud ruum). Poeedirahu kohalikke tunnusjooni esitatakse samuti varieeruvalt, millest kujuneb omailma ambivalentsus: see on korraga paradiislik ja hõllanduslik, helge, meeldiv ja rahulik; teisalt aga sünge, tume ja rahutu, memento mori'st juhitud. Selle põhjal tuleb Poeedirahus välja ka kaks maastikuideaali, mille alusel see omailm konstrueeritakse: subjekti ümbritsev olevikuline hele, lage ja avar maastik, kaugusse avatud idüllilised väljad; ja teiseks metsik, räämas, vana maastik, mille tegelik tähendus jääb kättesaamatusse minevikku, nagu näiteks leskede hooletusse kasvanud koduaiad (vohavat kirjeldust vt Kasemaa 2012b: 50-52) või unustatud, võssa kasvanud kabeliaed (vt Kasemaa 2012b: 100).

Oma loominguga annab Kasemaa nähtavuse ühele intiimsele koha- või koguni maailmakogemusele ja heidab valgust muidu märkamatutele subjektiivsetele tähendustele, mis võimendavad Poeedirahu üheks fenomenaalseks omailmaks.

Artikkel on valminud grandi nr ETF9035 („Adressaadi dünaamika eesti elulookirjutuses”) raames.

\section{Kirjandus}

B u n k š e, Edmunds Valdemārs 2012. Geograafia ja elamise kunst. Tallinn: Varrak.

D e e ly, John 2009. Semiootika alused. Tartu Semiootika Raamatukogu 4.1. Tartu: Tartu Ülikooli Kirjastus.

J e n n ing s, Ken 2012. Kaardikirg. Geograafianohikute kirev maailm. (Imeline Teadus.) Tallinn: Äripäev.

K a s e m a a, Andrus 2008. Poeedirahu. Tartu: Ilmamaa.

$\mathrm{K}$ a s e m a a, Andrus 2009a. Andrus Kasemaa elektronkirjad 15. V - 11. VI 2009.

$\mathrm{K}$ a s e m a a, Andrus 2009b. Lagunemine. Tallinn: Eesti Keele Sihtasutus.

$\mathrm{K}$ a s e m a a, Andrus 2012a. Kustutamatud õhtud. Tallinn: Tuum.

$\mathrm{K}$ a s e m a a, Andrus 2012b. Leskede kadunud maailm. Tallinn: Varrak.

$\mathrm{K}$ a s e m a a, Andrus 2013. Ehalkäimisest. - Looming, nr 1, lk 84-94.

K a u s, Jan 2008. Poeedi aeglus. - Sirp 7. XI, lk 4-5.

L i i v, Juhan 1921. Enesest ja teistest. Juhan Liivi kogutud teoksed I. Tartu: NoorEesti.

M a r a n, Timo 2001. Mõtteid Kaplinski omailmast. - Keel ja Kirjandus, nr 3, lk 181-184.

Melts, Brita 2010. Luuletaja omailm: Andrus Kasemaa Poeedirahu ja Mats Traadi Harala. Magistritöö. Tartu Ülikool, Kirjanduse ja teatriteaduse osakond. 
P a r h o m e n k o, Eduard 2009. Martin Heidegger. - 20. sajandi mõttevoolud. Toim

Epp Annus. Heuremata. Tallinn-Tartu: Tartu Ülikooli Kirjastus, lk 229-262.

R u m m o, Paul-Eerik 2010. Autori uutmoodi uuestisünd. - Looming, nr 4, lk 589_ 591.

T o m berg, Jaak 2009. Poeedi lagunemise passiivne ja rikastav rahu. - Sirp 14. VIII, lk 7.

$\mathrm{T} \mathrm{u}$ a n, Yi-Fu 1981. Space and Place. The Perspective of Experience. Third printing. Minneapolis: University of Minnesota Press.

T ü ü r, Kadri 2002. Koht ja kohatus Karl Ristikivi romaanides „Kõik, mis kunagi oli” ja „Ei juhtunud midagi”. - Aare Pilv, Kadri Tüür, Sündmus. Koht. (Collegium litterarum 15.) Tallinn: Underi ja Tuglase Kirjanduskeskus, lk 69-192.

T ü ü r, Kadri 2011. Bird Sounds in Nature Writing: Human Perspective on Animal Communication. - Umweltphilosophie und Landschaftsdenken im baltischen Kulturraum. Environmental Philosophy and Landscape Thinking. Toim Liina Lukas, Ulrike Plath, Kadri Tüür. (Collegium litterarum 24.) Tallinn: Underi ja Tuglase Kirjanduskeskus, lk 154-178.

U e x k ü l1, Jakob von 2012. Omailmad. Koost Kalevi Kull ja Riin Magnus. (Eesti mõttelugu 105.) Tartu: Ilmamaa.

Und u sk, Jaan 2011a. Das baltische Pantheon in der Naturphilosophie. Baer, Uexküll, Ostwald und das Problem der Zeit. - Umweltphilosophie und Landschaftsdenken im baltischen Kulturraum. Environmental Philosophy and Landscape Thinking. Toim Liina Lukas, Ulrike Plath, Kadri Tüür. (Collegium litterarum 24.) Tallinn: Underi ja Tuglase Kirjanduskeskus, lk 112-136.

Undusk, Jaan 2011b. Umweltphilosophie und Naturdenken im baltischen Raum. Zur Einführung und Irritation. - Umweltphilosophie und Landschaftsdenken im baltischen Kulturraum. Environmental Philosophy and Landscape Thinking. Toim Liina Lukas, Ulrike Plath, Kadri Tüür. (Collegium litterarum 24.) Tallinn: Underi ja Tuglase Kirjanduskeskus, lk 15-21.

V a a r i k, Laura-Madleen 2009. „Sest nad on kõik põrmu- ja raipehaisulised luuletused”. - Värske Rõhk, III (nr 19), lk 87-89.

\section{Poeedirahu - Andrus Kasemaa's literary Umwelt}

Keywords: Andrus Kasemaa's oeuvre, Poeedirahu, Umwelt, mindscape, perceptual landscapes

The article analyses a subjective poetic world and terms it as a literary Umwelt. Poeedirahu 'lit. Poet's peace of mind' is a small place described by bits and pieces by Andrus Kasemaa (born 1984) throughout three collections of poetry and one prose work, using slight mentions, cues and significant objects. The name has been invented for a place whose geography recognizably coincides with the author's home environs, yet which represents, above all, a literary or mental space, thus vibrating on the fascinating boundary between the real and the imaginary. There is no such Poeedirahu anywhere in real Estonia. Although the prototypical surroundings can be found out, Poeedirahu is mainly a mindscape gradually established by literary works exactly as the author wishes his readers to see it.

When applied in literary studies the biosemiotic term Umwelt tends to become somewhat metaphorical, inevitably touching upon what belongs to cultural 
geography. This way it should rather be termed as a mindscape containing both the real and the imaginary, the autobiographical and the fictional, the landscapes created in texts as well as their real prototypes coinciding with the author's home surroundings, involving the author's geographic perception, his inner man, his deliberate selection of the surrounding objects and his imaginations, as well as the projection of all this into his works via the meaningful elements belonging to the narrator's space.

Poeedirahu as a creative world built purposefully with the involvement of the author's senses, will and aspirations looks successfully accessible for literary analysis via the bio-semiotic mindscape model, which is indeed one of the most alluring ways to address the author's home-inspired personal mythology and his home-centered lyric „I”.

Brita Melts (b. 1984), MA, doctoral student at the Institute of Cultural Research and Fine Arts, University of Tartu, ephemera@ut.ee 